\title{
Netralitas Politik Aparatur Sipil Negara dalam Perspektif Perlindungan Hak Asasi Manusia
}

\author{
Muhammad Riora ${ }^{1 *}$, Ulya Kencana ${ }^{2}$, Kun Budianto ${ }^{3}$ \\ ${ }^{1}$ Prodi S2 Hukum Tatanegara Fakultas Syariah dan Hukum Universitas Islam Negeri Raden Fatah Palembang, Jln. Seruni \\ No. 42 RT 019 RW 006 Kelurahan Bandar Jaya Kec. Lahat Kab. Lahat, \\ ${ }^{2}$ Fakultas Syariah dan Hukum Universitas Islam Negeri Raden Fatah Palembang, \\ Jl. Pembangunan No 5 Rt 002 Rw 009 Siring Agung Ilir Barat 1 Palembang, \\ ${ }^{3}$ Fakultas Ilmu Sosial dan Ilmu Politik Universitas Islam Negeri Raden Fatah Palembang, \\ Jln Embacang RT 34 RW 12 kelurahan 30 Ilir kecamatan IB 2 Palembang, \\ *Correspondence email: rioraadhyaksa@gmail.com; ulyakencana_uin@radenfatah.ac.id; kunbudianto@yahoo.co.id
}

\begin{abstract}
Abstrak. Dalam aspek hukum dan pemerintahan, reformasi birokrasi menjadi hal yang sangat mendesak untuk segera direalisasikan, termasuk kebijakan netralitas politik ASN. Oleh karena itu, penelitian ini bertujuan untuk menganalisis kebijakan netralitas politik ASN menurut Undang-Undang Nomor 5 Tahun 2014 Tentang Aparatur Sipil Negara dalam Perspektif Perlindungan HAM. Ruang lingkup penelitian ini dilakukan dengan cara menarik asas hukum terhadap hukum positif tertulis. Asas hukum digunakan dalam menafsirkan Undang-Undang Nomor 5 Tahun 2014 tentang ASN dengan mengkaitkannya dalam perspektif perlindungan Hak Asasi Manusia. Metode yang dipakai adalah penelitian hukum yuridis normatif dengan menggunakan data sekunder. Hasil penelitian mengungkapkan bahwa setiap ASN tidak berpihak dengan segala bentuk pengaruh manapun dan kepentingan siapapun. Dalam hal ini terdapat pembatasan hak politik ASN menurut Undang-Undang Nomor 5 Tahun 2014 Tentang Aparatur Sipil Negara tidak melanggar HAM seperti yang diatur dalam Undang-Undang Dasar Negara Republik Indonesia Tahun 1945. Adapun menurut asas hukum Islam, ASN harus netral dan patuh terhadap pemimpin terpilih tanpa memusuhinya. Dengan demikian, disimpulkan bahwa Kebijakan netralitas politik ASN telah memenuhi 4 indikator sebuah negara hukum, yaitu ada perlindungan HAM, pembagian kekuasaan, pemerintahan yang berdasarkan hukum dan peraturan perundang-undangan, dan peradilan tata usaha negara.
\end{abstract}

Kata Kunci : Aparatur Sipil Negara; Netralitas Politik; HAM.

Abstract. In the legal and governmental aspects, bureaucratic reform is very urgent to be realized, including the policy of ASN political neutrality. Therefore, this study aims to analyze the political neutrality policy of ASN according to Law Number 5 of 2014 concerning State Civil Servants in the Perspective of Human Rights Protection. The scope of this research is carried out by drawing legal principles against written positive law. Legal principles are used in interpreting Law Number 5 of 2014 concerning $A S N$ by relating it to the perspective of protecting human rights. The method used is normative juridical legal research using secondary data. The research results reveal that every civil servant organization does not take sides with any form of influence and interests of anyone. In this case, there are restrictions on the political rights of ASN according to Law Number 5 of 2014 concerning State Civil Servants not violating human rights as stipulated in the 1945 Constitution of the Republic of Indonesia. According to the principles of Islamic law, ASN must be neutral and obedient to leaders. Elected without antagonizing him. Thus, it is concluded that the ASN political neutrality policy has met 4 indicators of a rule of law, namely protection of human rights, distribution of power, governance based on laws and regulations, and state administrative court.

Keywords: State Civil Apparatus; Political Neutrality; Human Rights.

\section{PENDAHULUAN}

Di Era Reformasi, menuntut perubahan mendasar pada seluruh aspek kehidupan antara lain sistem hukum, pemerintahan, ekonomi dan politik yang demokratis. Reformasi birokrasi merupakan langkah-langkah koreksi terhadap kebijakan politik pemerintah masa lalu. Menurut Mokhsen, pemahaman netralitas ASN di Indonesia masih terlalu dominan pada aspek politik, idealnya netralitas mengacu pada makna impartiality yaitu bebas kepentingan, bebas intervensi, bebas pengaruh, adil, objektif, dan tidak memihak ${ }^{1}$. Alasan pembatasan hak asasi ASN berupa hak atas kebebasan menyatakan pendapat dan ekspresi terkait pilihan politik bagi ASN tersebut sudah proporsional, dan bukansekedar kebijakan yang bersifat ad hoc. Dalam aspek hukum dan pemerintahan, reformasi birokrasi menjadi hal yang sangat mendesak untuk segera direalisasikan.

Pasca berakhirnya rezim pemerintahan Orde Baru banyak terjadi krisis diberbagai bidang. Indonesia memasuki babak baru yang disebut Era Reformasi, yang lahir sebagai tuntutan rakyat agar ada perubahan mendasar pada seluruh aspek kehidupan antara lain sistem hukum, pemerintahan, ekonomi dan politik yang demokratis. Dalam aspek hukum dan pemerintahan, reformasi birokrasi menjadi hal yang sangat mendesak untuk segera direalisasikan. Kasus

1 Mokhsen, Nuraida. FGD Sistem Pengawasan KASN Terhadap Pelaksanaan Asas Netralitas ASN, Jakarta 21 Mei 2018. dikutip dari E-Book Pengawasan Netralitas Aparatur Sipil Negara Tahun 2019. 
pelanggaran netralitas politik ASN yang paling banyak terjadi adalah ASN memberikan dukungan melalui media sosial atau media massa, lalu kasus ASN yang melakukan pendekatan maupaun mendaftarkan diri pada salah satu partai politik, dan ada juga yang melakukan sosialisasi sebagai bakal calon melalui alat peraga kampanye. ${ }^{2}$

Hal itu dijadikan alat untuk mendukung pemenangan organisasi politik tertentu untuk mempertahankan kekuasaan pemerintah pada saat itu. Birokrasi pemerintah merupakan aktor utama pelayanan publik yang harus mengutamakan pelayanan yang adil kepada masyarakat. Reformasi birokrasi merupakan langkah-langkah koreksi terhadap kebijakan politik pemerintah setelah berakhirnya rezim Orde Baru.

Salah satu langkah mendasar dari reformasi birokrasi, pemerintah telah menetapkan kebijakan baru dalam pembinaan ASN. Pada masa Orde Baru, bahwa sikap politik ASN harus mendukung golongan politik tertentu. Pasca runtuhnya Orde Baru di era Reformasi menjadi netral atau tidak memihak. Hal ini selanjutnya disebut netralitas politik ASN. Netralitas politik ASN merupakan pilar penting dalam kelangsungan terselenggaranya pemerintahan yang baik (good governance), berhasil dan berdaya guna.

ASN merupakan profesi bagi Pegawai Negeri Sipil (PNS) dan Pegawai Pemerintah dengan Perjanjian Kerja (PPPK) yang bekerja pada instansi pemerintah yang diangkat oleh Pejabat Pembina Kepegawaian (PPK), yaitu Menteri/Gubernur/Bupati/Walikota dan diserahi tugas dalam suatu jabatan pemerintahan atau diserahi tugas negara lainnya dan digaji berdasarkan peraturan perundang-undangan. Pegawai Negeri Sipil yang selanjutnya disingkat dengan PNS, adalah warga negara Indonesia yang memenuhi syarat tertentu, diangkat sebagai pegawai ASN secara tetap oleh pejabat pembina kepegawaian untuk menduduki jabatan pemerintahan. ${ }^{3}$

Berdasarkan Undang-Undang Nomor 5 Tahun 2014 Tentang Aparatur Sipil Negara Pasal 2 huruf f disebutkan bahwa penyelenggaraan kebijakan dan manajemen ASN berdasarkan pada asas netralitas, yang artinya bahwa setiap pegawai ASN tidak berpihak dengan segala bentuk pengaruh manapun dan tidak memihak kepada kepentingan siapapun. Selain itu terdapat pada Pasal 9 Ayat (2) yang menyatakan, bahwa pegawai ASN harus bebas dari pengaruh dan intervensi semua golongan dan partai politik. SedangkanPasal 12 menyatakan Pegawai ASN berperan sebagai perencana, pelaksana, dan pengawas penyelenggaraan tugas umum pemerintahan dan pembangunan nasional melalui pelaksanaan kebijakan dan pelayanan publik yang professional, bebas dari intervensi politik, serta bersih dari praktik korupsi, kolusi dan nepotisme.

Menteri Pendayagunaan Aparatur Negara dan Reformasi Birokrasi (Menpan RB) diakhir Desember 2017, telah mengeluarkan Surat Edaran (SE) Nomor B/71/M.SM.00.00/2017 tentang Pelaksanaan Netralitas bagi ASN dalam penyelenggaraan Pilkada Serentak 2018, Pileg 2019 dan Pilpres 2019. Salah satu poin pokok yang dijabarkan dalam SE Menpan RB ini adalah Pasal 11 huruf c Peraturan Pemerintah (PP) Nomor 42 Tahun 2004 tentang Pembinaan Jiwa Korps dan Kode Etik ASN, yang menyebutkan bahwa"Dalam hal etika terhadap diri sendiri, ASN wajib menghindari konflik kepentingan pribadi, kelompok, maupun golongan“".

Ada tujuh bentuk larangan bagi ASN yang dikonstruksi oleh Pemerintah berdasarkan PP Nomor 42 Tahun 2004 tersebut :

1. Melakukan pendekatan kepada Partai Politik (Parpol) terkait rencana pengusulan dirinya atau orang lain sebagai bakal calon.

2. Memasang spanduk/baliho yang mempromosikan dirinya atau orang lain.

3. Mendeklarasikan dirinya sebagai bakal calon.

4. Menghadiri deklarasi bakal pasangan calon, dengan atau tanpa atribut.

5. Mengunggah foto atau menanggapi (like, share, komentar dan sejenisnya) semua hal yang terkait dengan pasangan calon di media online dan media sosial.

6. Berfoto bersama dengan pasangan calon.

7. Menjadi pembicara/narasumber pada kegiatan pertemuan parpol. ${ }^{4}$

Menurut Komisioner Ombudsman RI 2016-2021, La Ode Ida, yang menangani pengaduan berkaitan dengan SDM Aparatur menyampaikan :

1. Wujud substansi pelayanan;

2. Terwujudnya profesionalisme birokrasi, yaitu ASN sebagai inti birokrasi yang melayani;

3. Terciptanya kenyamanan kerja ASN;

4. Tegaknya hukum yang berkeadilan. ${ }^{5}$

\footnotetext{
${ }^{2}$ Christina Kartika, "Hingga 27 Maret, Bawaslu Periksa 345 Kasus Pelanggaran Netralitas ASN", https://www.bawaslu.go.id/id/berita/hingga-27-maret-bawaslu-periksa-345-kasus-pelanggaran-netralitas-asn (diakses pada Tanggal 21 April 2020).

${ }^{3}$ Pasal 1 Angka 1 Undang-Undang Nomor 5 Tahun 2014 Tentang Aparatur Sipil Negara

${ }^{4}$ Herdiansyah Hamzah, "Netralitas ASN dalam Pilkada", https://www.herdi.web.id/netralitas-asn-dalam-pilkada/ (diakses pada 18 April 2019).
} 
Peraturan netralitas politik ASN tersebut tidak sejalan dengan kenyataan yang ada saat ini. Karena masih banyak ASN yang melakukan pelanggaran netralitas dari aspek politik. Berdasarkan dokumen laporan Komisi Aparatur Sipil Negara (KASN) Tahun 2019, jumlah pelanggaran netralitas politik ASN dalam Pemilihan Kepala Daerah (Pilkada) serentak 2018 dan Pemilihan Presiden (Pilpres) 2019 cukup tinggi. Hal ini tercermin dari data pengaduan pelanggaran netralitas pegawai ASN yang telah dilaporkan kepada KASN pada Tahun 2019 sebagai berikut:

Terdapat 337 kasus yang tersebar di beberapa daerah di Indonesia meliputi Provinsi Sulawesi Utara 53 kasus, Sulawesi Selatan 41 kasus, Jawa Tengah 28 kasus, Sulawesi Tengah 26 kasus, Sulawesi Utara 24 kasus, Sulawesi Barat 23 kasus, Sumatera Barat 16 kasus, Nusa Tenggara Barat 16 kasus, Maluku Utara 11 kasus, Kalimantan Timur 10 kasus, Gorontalo 9 kasus, Lampung 8 kasus, Jawa Barat 8 kasus, Aceh 8 kasus, Riau 8 kasus, Kalimantan Barat 7 kasus, dan wilayah lain sebanyak 48 kasus. $^{6}$

Laporan sampai dengan bulan Maret 2020, meskipun saat ini sedang terjadi pandemi virus corona, Badan Pengawas Pemilu (Bawaslu) Republik Indonesia telah memeriksa sebagai berikut.

Sebanyak 345 kasus dugaan pelaggaran netralitas politik ASN dari seluruh wilayah Indonesia yang akan menggelar Pemilihan Kepala Daerah (Pilkada) serentak. Dari 345 kasus, Bawaslu telah melakukan pemeriksaan sebanyak 297 kasus dan telah meyerahkan hasil rekomendasinya kepada Komisi Aparatur Sipil Negara (KASN). Sejumlah 37 kasus dihentikan dan 11 masih dalam proses pemeriksaan. Kasus pelanggaran netralitas politik ASN yang paling banyak terjadi, adalah ASN memberikan dukungan melalui media sosial atau media massa, lalu kasus ASN yang melakukan pendekatan maupaun mendaftarkan diri pada salah satu partai politik, dan ada juga yang melakukan sosialisasi sebagai bakal calon melalui alat peraga kampanye. ${ }^{7}$

Pegawai ASN berada dalam posisi yang dilematis oleh kepentingan politik. Di satu sisi, mereka adalah pegawai yang diangkat, ditempatkan, dipindahkan dan diberhentikan oleh Pejabat Pembina Kepegawaian (PPK) yaitu Gubernur/Bupati/Walikota yang berstatus sebagai pejabat politik.Kondisi seperti ini membuat karier mereka sering dikaitkan dengan kepentingan politik PPK. Di sisi lain, ASN juga harus tetap bersikap netral untuk menjaga profesionalitasnya dalam menjalankan tata kelola pemerintahan dan pelayanan publiknya. ASN merupakan pelaksana kebijakan dan pemegang kekuasaan dan kewenangan dalam pengelolaan anggaran dan sumber daya di dalam birokrasi. Hal ini mengakibatkan pegawai ASN dapat dijadikan sebagai "alat" bagi pejabat politik untuk dapat tetap mempertahankan/mendapatkan kewenangan dan kekuasaannya.

Wujud langkah reformasi di bidang hukum, pemerintah telah melakukan perubahan (amandemen) atas UndangUndang Dasar Negara Republik Indonesia Tahun 1945 secara bertahap sebanyak empat kali yang berlangsung mulai tahun1999 sampai dengan 2002. Pada perubahan ke-dua telah ditambahkan Bab XA tentang Hak Asasi Manusia (HAM) terdiri 10 (sepuluh) Pasal, yaitu Pasal 28A sampai dengan Pasal 28J. Penambahan ketentuan ini memperkuat landasan konstitusional pengakuan dan perlindungan Hak Asasi Manusia (HAM) di Indonesia. Dalam Pasal-pasal Undang-Undang Dasar Negara Republik Indonesia Tahun 1945 mengenai HAM tersebut terdapat Pasal-pasal yang berkaitan dengan hak-hak politik, antara lain :

1. Pasal 28C ayat (2), menyatakan bahwa "Setiap orang berhak untuk memajukan dirinya dalam memperjuangkan haknya secara kolektif untuk membangun masyarakat, bangsa dan negaranya".

2. Pasal 28D ayat (3), menyatakan bahwa "Setiap warga negara berhak memperoleh kesempatanyang sama dalam pemerintahan".

3. Pasal 28 E ayat (3), menyatakan bahwa "Setiap orang berhak atas kebebasan berserikat, berkumpul dan mengeluarkan pendapat".

Berkaitan denga pelaksanaan perlindungan HAM diatur dalam pasal-pasal:

Pasal 28 I, menyatakan bahwa "Hak untuk hidup, hak untuk tidak disiksa, hak untuk kemerdekaan pikiran dan hati nurani, hak beragama, hak untuk tidak diperbudak, hak untuk diakui sebagai pribadi dihadapan hukum, dan hak

${ }^{5}$ Ida, La Ode. FGD Sistem Pengawasan Netralitas ASN dalam Aspek Politik, Pelayanan Publik, dan Manajemen ASN, Jakarta 5 September 2018

${ }^{6}$ Septiana Dwiputrianti, dkk. Pengawasan Penegakan Netralitas (Impartiality) Aparatur Sipil Negara, (Jakarta: Komisi Aparatur Sipil Negara, 2019)

${ }^{7}$ Christina Kartika, "Hingga 27 Maret, Bawaslu Periksa 345 Kasus Pelanggaran Netralitas ASN", https://www.bawaslu.go.id/id/berita/hingga-27-maret-bawaslu-periksa-345-kasus-pelanggaran-netralitas-asn (diakses pada Tanggal 21 April 2020). 
untuk tidak dituntut atas dasar hukum yang berlaku surut adalah hak asasi manusia yang tidak dapat dikurangi dalam keadaan apapun".

Pasal 28J menyatakan bahwa:

(1) Setiap orang wajib menghormati hak asasi manusia orang lain dalam tertibkehidupan bermasyarakat, berbangsa, dan bernegara.

(2) Dalam menjalankan hak dan kebebasannya, setiap orang wajib tundukkepada pembatasan yang ditetapkan dengan undang-undang dengan maksudsemata-mata untuk menjamin pengakuan serta penghormatan atas hak dankebebasan orang lain dan untuk memenuhi tuntutan yang adil sesuai denganpertimbangan moral, nilai-nilai agama, keamanan, dan ketertiban umum dalam suatu masyarakat demokratis.

Berkaitan dengan pencantuman pasal-pasal HAM dalam amandemen Undang-Undang Dasar Negara Republik Indonesia Tahun 1945 tersebut, perlu dikaji kembali kebijakan netralitas politik ASN dalam Undang-Undang Nomor 4 Tahun 2015 tentang Aparatur Sipil Negara sebagai bagian dari sistem hukum nasional. Menurut Lon L. Fuller, bahwa hukum sebagai sistem maka ia harus memenuhi 8asas atau principles of legality sebagai berikut:

1. Sistem hukum harus mengandung peraturan-peraturan, artinya ia tidak boleh mengandung sekadar keputusankeputusan yang berfisat ad hoc.

2. Peraturan-peraturan yang telah dibuat itu harus diumumkan.

3. Peraturan tidak boleh berlaku surut.

4. Peraturan-peraturan disusun dalam rumusan yang bisa dimengerti.

5. Suatu sistem tidak boleh mengandung peraturan-peraturan yang bertentangan satu sama lain.

6. Peraturan-peraturan tidak boleh mengandung tuntutan yang melebihi apa yang dapat dilakukan.

7. Peraturan tidak boleh sering diubah-ubah.

8. Harus ada kecocokan antara peraturan yang diundangkan dengan pelaksanaannya sehari-hari. ${ }^{8}$

Sinkronisasi peraturan perundang-undangan dilakukan untuk mengetahui pengaturan kebijakan netralitas politik ASN menurut Undang-Undang Nomor 5 Tahun 2014 tentang Aparatur Sipil Negara telah sesuai dan tidak bertentangan dengan nilai-nilai perlindungan HAM yang ada di dalam Undang-Undang Dasar Negara Republik Indonesia Tahun 1945 hasil amandemen. Dalam hal ini alasan pembatasan hak asasi ASN berupa hak atas kebebasan menyatakan pendapat dan ekspresi terkait pilihan politik bagi ASN tersebut sudah proporsional dan bukan sekedar kebijakan yang bersifat ad hoc.

Al-Qur'an menjelaskan, bahwa manusia merupakan ciptaan Allah SWT yang memiliki kesamaan hak satu sama lainnya termaktub dalam al-Quran surat Al-Hujurat Ayat 13. Firman Allah SWT tersebut menunjukkan bahwa dalam menjalani kehidupan ini, hendaknya kita dapat menerima sebuah perbedaan dan menilainya sebagai rahmat dari Allah SWT dan menerima eksistensi kemanusiaan, bahwa manusia merupakan ciptaan Allah yang memiliki kesamaan hak satu sama lainnya tanpa terkecuali.

Berdasarkan uraian di atas, terdapat permasalahan yang harus dikaji lebih mendalam yaitu tentang kebijakan netralitas politik ASN menurut Undang-Undang Nomor 5 Tahun 2014 Tentang Aparatur Sipil Negara, dan kebijakan netralitas politik ASN ditinjau dari aspek perlindungan HAM. Penelitian ini diberi judul "Kebijakan Netralitas Politik Aparatur Sipil Negara Menurut Undang-Undang Nomor 5 Tahun 2014 dalam Perspektif Perlindungan HAM".

Penelitian ini merupakan penelitian hukum normatif yaitu penelitian bahan kepustakaan menggunakan data sekunder yang meliputi bahan hukum primer, bahan hukum sekunder, dan bahan hukum tersier. Selanjutnya dilakukan analisis kualitatif yang berhubungan dengan masalah yang diteliti. Sumber hukum ataupun kepustakaan dari penelitian ini adalah buku-buku tentang Aparatur Sipil Negara (ASN) dan Hak Asasi Manusia (HAM), peraturan perundangundangan di Indoneisa yang relevan dengan penelitian, dan pengamatan penulis terkait penelitian ini.

Hasil penelitian menunjukkan bahwa kebijakan netralitas politik Aparatur Sipil Negara (ASN) menurut Undang-Undang Nomor 5 Tahun 2014 Tentang Aparatur Sipil Negara yang berlaku saat ini mempunyai keabsahan dan kekuatan hukum karena telah dituangkan dalam bentuk undang-undang. Adapun bentuk kebijakan netralitas politik ASN menurut undang-undang adalah Pasal 2 huruf $\mathbf{f}$ disebutkan bahwa penyelenggaraan kebijakan dan manajemen ASN berdasarkan pada asas netralitas yang artinya bahwa setiap pegawai ASN tidak berpihak dengan segala bentuk pengaruh manapun dan tidak memihak kepada kepentingan siapapun. Selain itu terdapat juga pada Pasal 9 Ayat (2) yang menyatakan bahwa pegawai ASN harus bebas dari pengaruh dan intervensi semua golongan dan partai politik. Sedangkan Pasal 12 menyatakan Pegawai ASN berperan sebagai perencana, pelaksana, dan pengawas penyelenggaraan tugas umum pemerintahan dan pembangunan nasional melalui pelaksanaan kebijakan dan pelayanan publik yang professional, bebas dari intervensi politik, serta bersih dari praktik korupsi, kolusi dan 
nepotisme. Kemudian pembatasan hak politik ASN yang diatur dalam undang-undang tersebut tetaplah pembatasan HAM, akan tetapi tidak melanggar hak individu ASN karena hak tersebut merupakan Hak Asasi Manusia yang boleh dibatasi (derogable rights).

Berdasarkan latar belakang permasalahan di atas, rumusan masalah penelitian ini adalah tentang bentuk kebijakan netralitas politik ASN menurut Undang-Undang Nomor 5 Tahun 2014 Tentang Aparatur Sipil Negara, dan kebijakan netralitas politik ASN Menurut Undang-Undang Nomor 5 Tahun 2014 dalam Perspektif Perlindungan HAM.

Kerangka teori merupakan konstruksi pemikiran (logical construct) yang dibangun sebagai susunan pola pikir yang sistematis, berdasarkan pada konsep-konsep penelitian atau berdasarkan teori-teori yang akan digunakan untuk menjawab atau memecahkan permasalahan yang diteliti. Kerangka teori adalah teori-teori hukum yang digunakan untuk membedah permasalahan yang ada dalam penelitian, sebagai alat analisis dalam menemukan jawaban dari permasalahan hukum. ${ }^{9}$ Teori yang digunakan sebagai alat analisis dalam penelitian ini:

\section{Teori Kebijakan}

Pemerintah dalam menyelenggarakan tugas-tugas negara banyak mengeluarkan kebijakan yang dituangkan dalam berbagai bentuk seperti beleidslijnen (garis-garis kebijakan), het beleid (kebijakan), voorschriften (peraturanperaturan), richtlijnen (pedoman-pedoman), regelingen (petunjuk-petunjuk), circulaires (surat edaran), resoluties (resolusi-resolusi), aanschrijvingen (instruksi-instruksi), beleidsnota's (nota kebijakan), reglemen (ministriele), (peraturan-peraturan menteri), keputusan-keputusan, dan pengumuman. ${ }^{10}$

Peraturan kebijakan merupakan suatu peraturan umum tentang pelaksanaan wewenang pemerintah terhadap warga negara yang ditetapkan berdasarkan kekuasaan sendiri oleh instansi pemerintahan yang berwenang atau isntansi pemerintah yang secara hierarki lebih tinggi. Kebijakan secara esensial berkenaan dengan:

1. Organ pemerintahan, dalam hal ini semata-mata menggunakan kewenangan untuk menjalankan tindakan-tindakan pemerintahan.

2. Kewenangan pemerintahan itu tidak terikat dengan tegas.

3. Ketentuan umum, digunakan pada pelaksanaan kewenangan. ${ }^{11}$

Dalam kamus politik yang ditulis Marbun, dikatakan "Kebijakan merupakan rangkaian konsep serta asas yang menjadi garis besar dan juga dasar rencana dalam pelaksanaan satu pekerjaan, kepemimpinan dalam pemerintahan atau juga organisasi pernyataan cita-cita, tujuan, prinsip atau juga maksud sebagai garis pedoman dalam mencapai sasaran." Secara umum kebijakan merupakan aturan yang tertulis yang merupakan formal organisasi yang memiliki sifat mengikat anggota yang terkait dengan organisasi tersebut, yang bisa mengatur perilaku dengan tujuan menciptakan tata nilai baru di dalam masyarakat.

Menurut Mustopadidjaja, kebijakan ialah suatu keputusan suatu organisasi yang dimaksudkan untuk dapat mengatasi permasalahan tertentu sebagai keputusan atau untuk mencapai tujuan tertentu, berisikan ketentuanketentuan yang bisa dijadikan pedoman perilaku dalam pengambilan sebuah keputusan lebih lanjut, yang harus dilakukan baik itu kelompok sasaran ataupun (unit) suatu organisasi pelaksana kebijakan dan penerapan atau juga pelaksanaan dari suatu kebijakan yang sudah ditetapkan baik dalam hubungan dengan (unit) organisasi pelaksana ataupun dengan kelompok sasaran yang dimaksudkan. ${ }^{12}$

Kebijakan yang diteliti adalah Undang-Undang Nomor 5 Tahun 2014 Tentang Aparatur Sipil Negara, bahwa setiap pegawai ASN tidak berpihak dengan segala bentuk pengaruh manapun dan tidak memihak kepada kepentingan siapapun, dan Undang-Undang Dasar Negara Republik Indonesia Tahun 1945, yang secara bertahap sebanyak empat kali yang berlangsung mulai tahun1999 sampai dengan 2002. Pada perubahan ke-dua telah ditambahkan Bab XA tentang Hak Asasi Manusia (HAM).

\section{Teori Politik}

Politik tidak bisa dilepaskan dari kehidupan manusia baik disadari atau tidak, mau atau tidak, politik ikut memengaruhi kehidupan orang sebagai individu maupun sebagai bagian dari kelompok masyarakat. Hal ini berlangsung sejak kelahiran sampai kematian. Politik memengaruhi kehidupan semua orang, maka Aristoteles

${ }^{9}$ Panduan Penulisan Tesis Prodi Magister Hukum Tata Negara Fakultas Syariah dan Hukum UIN Raden Fatah Palembang, 2019, hlm. 9.

${ }^{10}$ Ridwan HR, Hukum Administrasi Negara, (Jakarta: Rajagrafindo Persada, 2011), hlm. 174.

${ }^{11}$ Ibid, hlm. 177.

${ }^{12}$ Parta Ibeng, Pengertian Kebijakan, https://pendidikan.co.id/kebijakan-pengertian-tingkatan-macam-menurut-para-ahli/ (diakses pada 25 Mei 2020). 
mengatakan bahwa politik merupakan master of sciences. Bagi Aristoteles, politik berarti mengatur apa yang seyognyanya dilakukan dan apa yang seyognyanya tidak dilakukan. ${ }^{13}$

Politik secara etimologi berasal dari bahasa Yunani Kuno, yaitu "Polis". Polis adalah negara yang luasnya sebesar kota yang terdapat dalam budaya Yunani Kuno, yang saat itu kota dianggap identik dengan negara. Dari Polis berkembang beragam konsep seperti politeia yang bermakna segala hak ikhwal yang menyangkut negara, polites yang bermakna warga negara, politikos yang berarti kewarganegaraan, liticos yang bermakna ahli negara. Orang Romawi mengambil alih perkataan Yunani tersebut lalu menamakan pengetahuan tentang negara/pemerintah dengan istilah ars politica, artinya kemahiran tentang masalah-masalah kenegaraan. Dari penjelasan etimologis tersebut, disimpulkan bahwa politik sebagai sesuatu yang berhubungan antara warga negara pada suatu (negara) kota atau berdasarkan pengertian di atas, maka politik pada hakikatnya merupakan seni dan ilmu memerintah. ${ }^{14}$

Beberapa pendapat ahli tentang pengertian politik antara lain, menurut Andrew Heywood bahwa politik memiliki arti suatu kegiatan bangsa yang memiliki tujuan dalam membuat, mempertahankan, dan mengamandemen berbagai peraturan yang umum mencangkup mengatur kelangsungannya. Dalam hal ini tidak terlepas dari gejala konflik serta kerjasama. Roger Soltau menjelaskan politik adalah sebuah ilmu yang meneliti negara, tujuan negara, serta lembaga negara yang ada didalamnya yang mana melaksanakan tujuan tersebut, termasuk hubungan antara negara terhadap warga negaranya dan juga negara lain. Ramlan Surbakti menjelaskan politik memiliki arti tersendiri yakni sebuah proses interaksi dengan pemerintah serta masyarakat bertujuan menentukan kebaikan terhadap masyarakat yang berada pada suatu wilayah tertentu. ${ }^{15}$

Dalam hal isu penelitian, adalah ada keterkaitan isu bahwa terdapat politik hukum terhadap netralitas ASN dengan kepentingan golongan tertentu yang telah diatur dalam peraturan perundang-undangan telah menciderai aturan itu sendiri akibat ada unsur politik didalamnya.

\section{Teori Negara Hukum}

Muhammad Tahir Azhari mengungkapkan bahwa gagasan atau konsep Negara Hukum telah dikemukakan Plato dan Aristoteles, ketika mereka memproduksi konsep Nomio sebagai karya tulis ketiganya yang ditulis pada masa tuanya. Plato mengemukakan penyelenggaraan Negara yang baik, ialah yang didasarkan pada pengaturan hukum yang baik. Gagasan Plato tentang Negara hukum semakin tegas ketika didukung oleh muridnya Aristoteles. Menurutnya konsep Nomoi yang dapat dianggap sebagai cikal bakal pemikiran tentang Negara hukum. ${ }^{16}$

Selain konsep rechtsstaat dan the rule of law, gagasan negara hukum juga berkaitan dengan konsep nomocracy yang berasal dari perkataan nomos dan cratos. Perkataan nomokrasi dibandingkan dengan demos dan cratos dalam demokrasi. Nomos berarti norma, sedangkancratos adalah kekuasaan yang dibayangkan sebagai faktor penentu dalam penyelenggaraan kekuasaan adalah norma atau hukum. Istilah nomokrasi berkaitan erat dengan ide kedaulatan hukum atau prinsip hukum sebagai kekuasaan tertinggi. Dalam istilah Inggris dikembangkan A.V. Dicey. Hal itu dikaitkan dengan prinsip rule of law yang sesungguhnya dianggap sebagai pemimpin adalah hukum itu sendiri, bukan orang.Dalam buku Plato berjudul Nomoi yang diterjemahkan ke dalam bahasa Inggris dengan judul The Laws, tergambar ide nomokrasi sesungguhnya telah sejak lama dikembangkan dari zaman Yunani Kuno. ${ }^{17}$

Ide Negara hukum telah lama dikembangkan oleh filsuf dari zaman Yunani Kuno. Pemikiran Negara hukum merupakan gagasan modern yang meliputi perspektif dan selalu aktual. Pada masa Yunani Kuno pemikiran Negara hukum yang telah dibahas adalah negara yang berdiri berdasarkan hukum yang menjamin keadilan bagi warga negaranya. Pada zaman modern, konsep negara hukum Eropa Kontinental dikembangkan Immanuel Kant, Paul Laband, Julius Stahl, Fichte, dan lain-lain dengan menggunakan istilah Jerman, yaitu rechtsstaat. Dalam tradisi Anglo Saxon, konsep negara hukum dikembangkan oleh A.V. Dicey dengan sebutan The Rule of Law.

Menurut Immanuel Kant ada dua pokok yang menjadi inspirasi perkembangan prinsip-prinsip negara hukum, yaitu masalah pembatasan kekuasaan oleh para penguasa dan perlindungan Hak Asasi Manusia. Menurut Fredrich Julius Stahl, bahwa unsur Negara Hukum yang perlu dilindungi yaitu perlindungan Hak Asasi Manusia. Fredrich Julius Stahl mengungkapkan konsep Negara Hukum yang disebutnya dengan istilah rechtsstaat mencakup empat elemen penting yaitu:

1. Perlindungan hak asasi manusia;

2. Pembagian kekuasaan;

3. Pemerintahan berdasarkan undang-undang;

${ }^{13}$ Lihat, Ramlan Surbakti, Memahami Ilmu Politik, (Jakarta: Gramedia, 1992), hlm. 1.

${ }^{14}$ Lihat pembahasan pada, Efriza dan Yoyoh Rohaniah, Pengantar Ilmu Politik, (Malang: Intrans Publishing, 2015), hlm. 2.

${ }^{15} \mathrm{https} / / / \mathrm{www}$.ruangguru.co.id/20-pengertian-politik-dan-definisi-politik-menurut-para-tokoh-dan-ahli/ (diakses pada 27 Mei 2020).

${ }^{16}$ Muhammad Tahir Azhary, Negara Hukum, (Jakarta: Kencana, 2015), hlm. 14.

${ }^{17}$ Cst Kansil, Pengantar Ilmu Hukum Dan Tata Hukum Indonesia, (Jakarta: Balai Pustaka, 2002), hlm 3. 
4. Adanya peradilan tata usaha Negara. ${ }^{18}$

A. V. Dicey mengemukakan unsur-unsur The Rule of Law sebagai Supremacy of law, Equality before the law, Constitution based on human rights. ${ }^{19}$

Prinsip-prinsip rechtsstaat yang dikembangkan Julius Stahl tersebut pada pokoknya dapat digabungkan dengan ketiga prinsip The Rule of Law yang dikembangkan oleh A.V. Dicey untuk menandai ciri-ciri Negara Hukum modern di zaman sekarang. Oleh The International Commission of Jurist, prinsip-prinsip Negara Hukum ditambah lagi dengan prinsip peradilan bebas dan tidak memihak (independence and impartiality of judiciary), yang di zaman sekarang makin dirasakan mutlak diperlukan dalam setiap negara demokrasi. Prinsip-prinsip yang dianggap ciri penting Negara Hukum menurut The International Commission of Jurists, yaitu Negara harus tunduk pada hukum, Pemerintah menghormati hak-hak individu, dan Peradilan yang bebas dan tidak memihak. ${ }^{20}$

Terkait isu penelitian dikaji berdasarkan teori konsep negara hukum, terdapat unsur perlindungan Hak Asasi Manusia yang dalam hal ini adalah ASN, dan pemerintah harus berdasarkan undang-undang, yaitu pemerintah tidak melanggar aturan undang-undang terkait netralitas ASN dalam politik. Untuk itu diperlukan peradilan yang bebas dan tidak memihak apabila peraturan terciderai dan HAM ASN di langgar.

Teori Negara Hukum yang dikembangkan Fredrich Julius Stahl digunakan untuk menganalisis dan menemukan jawaban dari permasalahan pada penelitian ini. Teori ini dipakai untuk menganalisis kebijakan netralitas politik ASN di Indonesia dalam perspektif perlindungan Hak Asasi Manusia (HAM).

\section{HASIL DAN PEMBAHASAN}

\section{Bentuk Kebijakan Netralitas Politik ASN Menurut Undang-Undang Nomor 5 Tahun 2014 Tentang Aparatur Sipil Negara}

Aparatur Sipil Negara yang selanjutnya disingkat ASN adalah profesi bagi ASN dan pegawai pemerintah dengan perjanjian kerja yang bekerja pada instansi pemerintah ${ }^{21}$. Pegawai Aparatur Sipil Negara dan pegawai pemerintah dengan perjanjian kerjamerupakan pembantu pemerintahan yang diangkat oleh pejabat pembina kepegawaian dan diserahi tugas dalam suatu jabatan pemerintahan atau diserahi tugas negara lainnya dan digaji berdasarkan peraturan perundang-undangan. ASN merupakan pelaksana kebijakan pemerintah yang memiliki posisi penting dan tanggung jawab besar dalam proses pembangunan negara dan terciptanya pemerintahan yang baik (good governance). Artinya, tuntutan untuk bekerja secara profesional dan netral adalah sebuah kewajiban bagi seorang ASN. Ketidaknetralan ASN dapat menghambat pembangunan negara.

Afan Gafar mengatakan, bahwa kehadiran birokrasi sebagai instrumen kekuasaan dapat diwujudkan dalam bentuk memberi dukungan langsung kepada Golongan Karya pada setiap kali pemilihan umum diadakan. Pada pemilihan umum 1977, ASN memberikan suaranya buat Golkar. Jika kemudian ditambah dengan suara dari keluarga, seperti istri/suami, atau anak yang sudah berhak memilih Golkar akan mendapat sekitar 10 juta suara dari ASN dan keluarganya. Dengan demikian ASN menyumbang suara yang sangat berarti bagi Golkar. ${ }^{22}$

Pernyataan tersebut menunjukkan bahwa di era Orde Baru menjadi bukti paling nyata bahwa ASN tidak netral. Hal ini dapat berakibat negatif bagi pembangunan negara. Belajar dari kesalahan masa lalu, pemerintah kini mulai membenahi kualitas SDM aparatur melalui upaya reformasi birokrasi terutama dalam hal manajemen kepegawaian ASN dengan diterbitkannya Undang-Undang Nomor 5 Tahun 2014 Tentang Aparatur Sipil Negara. Undang-Undang Nomor 5 Tahun 2014 tentang Aparatur Sipil Negara (UU ASN) merupakan salah satu produk dari reformasi birokrasi pegawai pemerintah, salah satu poin pentingnya adalah kebijakan yang mengatur netralitas politik ASN.

Bentuk Kebijakan Netralitas Politik ASN Menurut UU ASN :

1. Asas netralitas tercantum pada Pasal 2 huruf f yang menyebutkan, bahwa penyelenggaraan kebijakan dan manajemen ASN berdasarkan pada asas netralitas yang artinya bahwa setiap pegawai ASN tidak berpihak dengan segala bentuk pengaruh manapun dan tidak memihak kepada kepentingan siapapun.

2. Pada Pasal 9 Ayat (2) yang menyatakan, bahwa pegawai ASN harus bebas dari pengaruh dan intervensi semua golongan dan partai politik.

3. Pasal 12, menyatakan Pegawai ASN berperan sebagai perencana, pelaksana, dan pengawas penyelenggaraan tugas umum pemerintahan dan pembangunan nasional melalui pelaksanaan kebijakan dan pelayanan publik yang professional, bebas dari intervensi politik, serta bersih dari praktik korupsi, kolusi dan nepotisme.

\footnotetext{
${ }^{18}$ Mahfud MD, Hukum dan Pilar-Pilar Demokrasi, (Yogyakarta: Gama Media, 1999), hlm 23.

${ }^{19}$ Diana Halim Koentjoro, Hukum Administrasi Negara, (Bogor: Ghalia Indonesia, 2004), hlm. 34

${ }^{20}$ Ibid

${ }^{21}$ Pasal 1 angka 1 Undang-undang No. 5 Tahun 2014 Tentang Aparatur Sipil Negara

${ }^{22}$ Afan Gaffar, Op.Cit
} 
Larangan ASN tidak boleh terlibat kegiatan politik dapat dilihat pada bagan berikut :

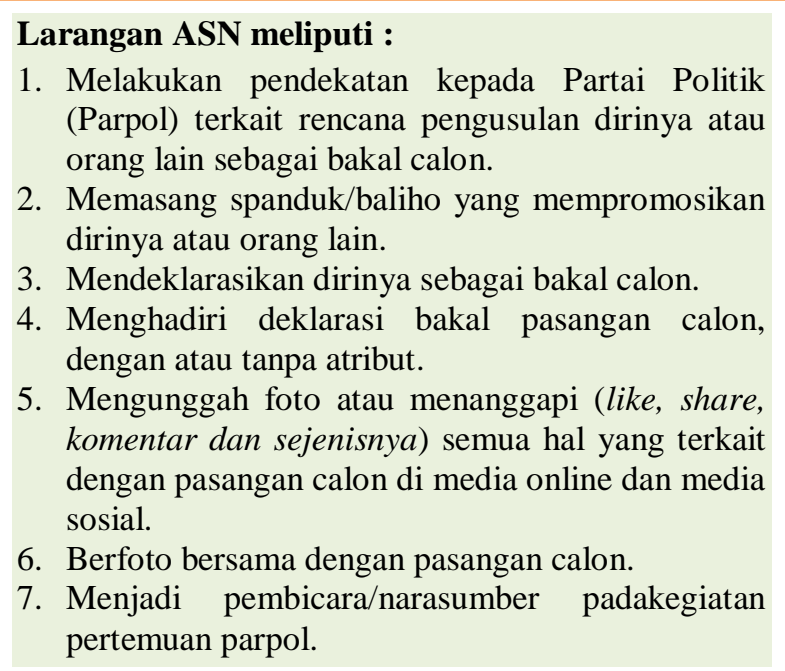

1. Melakukan pendekatan kepada Partai Politik (Parpol) terkait rencana pengusulan dirinya atau orang lain sebagai bakal calon.

2. Memasang spanduk/baliho yang mempromosikan dirinya atau orang lain.

3. Mendeklarasikan dirinya sebagai bakal calon.

4. Menghadiri deklarasi bakal pasangan calon, dengan atau tanpa atribut.

5. Mengunggah foto atau menanggapi (like, share, komentar dan sejenisnya) semua hal yang terkait dengan pasangan calon di media online dan media sosial.

6. Berfoto bersama dengan pasangan calon.

7. Menjadi pembicara/narasumber padakegiatan pertemuan parpol.

\section{Dasar Hukum}

- Undang-Undang Nomor 5 Tahun 2014 Tentang Aparatur Sipil Negara

- Peraturan Pemerintah Nomor 53 Tahun 2010 Tentang Disiplin Pegawai Negeri Sipil

- Surat Edaran Menpan RB Nomor B/71/M.SM.00.00/2017 Tanggal 27 Desember 2017 Tentang Pelaksanaan Netralitas ASN

\section{Kebijakan Netralitas Politik ASN Menurut Undang-Undang Nomor 5 Tahun 2014 dalam Pandangan Teori Negara Hukum Friedrich Julius Stahl}

Analisis kebijakan netralitas politik ASN dalam perspektif perlindungan HAM menggunakan Teori Negara Hukum Friedrich Julius Stahl. Menurutnya ada empat elemen penting sebuah negara hukum, yaitu :

a. Negara mengakui dan melindungi Hak Asasi Manusia (HAM).

b. Adanya pembagian kekuasaan (trias politica).

c. Pemerintahan harus berdasarkan peraturan hukum perundang-undangan.

d. Adanya Peradilan Tata Usaha Negara. ${ }^{23}$

Berdasarkan teori tersebut, disimpulkan bahwa dengan diterbitkannya peraturan berupa kebijakan netralitas politik Aparatur Sipil Negara yang tertuang dalam Undang-Undang Nomor 5 Tahun 2014 Tentang Aparatur Sipil Negara, adalah sah sesuai dengan teori negara hukum di atas karena beberapa alasan :

a. Undang-Undang tersebut telah memberikan perlindungaan HAM bagi Aparatur Sipil Negara.

b. Undang-Undang tersebut dibuat oleh lembaga legislatif selanjutnya dilaksanakan oleh pemerintah selaku lembaga eksekutif. Jika terdapat permasalahan hukum maka akan diadili oleh lembaga yudikatif. Ini menunjukkan adanya pembagian kekuasaan dalam proses penerbitan peraturan tersebut.

c. Mengingat pentingnya netralitas bagi seorang ASN karena peran pentingnya dalam pelayanan publik dalam pemerintahan, maka pemerintah menerbitkan sebuah peraturan perundang-undangan yang menjadi acuan pelaksanaan manajemen kepegawaian Aparatur Sipil Negara. Hal ini menunjukkan bahwa adanya pemerintahan yang berdasarkan hukum dan peraturan perundang-undangan.

d. Berlakunya suatu peraturan perundang-undangan tidak menutup kemungkinan akan adanya celah hukum yang dinilai merugikan seseorang atau golongan tertentu. Demikian halnya dengan penerbitan Undang-Undang Nomor 5 Tahun 2014 Tentang Aparatur Sipil Negara. Undang-Undang tersebut memberikan wadah bagi yang merasa dirugikan dengan berlakunya peraturan tersebut, yaitu salah satu caranya adalah mengajukan gugatan ke Pengadilan Tata Usaha Negara (PTUN).

\section{Kebijakan Netralitas Politik Aparatur Sipil Negara Dalam Perspektif Perlindungan HAM}

Berkaitan dengan kebijakan netralitas politik ASN menurut Undang-Undang Nomor 5 Tahun 2014 tentang Aparatur Sipil Negara dalam perspektif perlindungan HAM dengan pendekatan negara mengakui dan melindungi Hak Asasi Manusia (HAM).

Berkaitan dengan hak-hak asasi sebagaimana diatur dalam Undang-Undang Dasar Negara Republik Indonesia Tahun 1945dan peraturan perundang-undangan lain di Indonesia, maka hak bagi ASN untuk menyatakan pendapatnya terkait pilihannya kepada salah satu pasangan calon dalam sebuah kontestasi politik merupakan bagian dari hak asasi manusia yang dijamin secara konstitusional, yaitu hak mengeluarkan pendapat sebagaimana diatur dalam pasal $28 \mathrm{E}$ ayat (3) : Setiap orang berhak atas kebebasan berserikat, berkumpul dan mengeluarkan pendapat. 
Pembahasan hak politik ASN dalam perspektif perlindungan hak asasi manusia, bahwa ASN harus dipandang dalam kedudukannya sebagai warga negara sebagaimana tercantum juga dalam penjelasan umum Undang-Undang Nomor 5 Tahun 2014 Tentang Aparatur Sipil Negara bahwa:

"Pegawai ASN bukan saja dilihat dan diperlakukan sebagai aparatur negara tetapi juga harus dilihat dan diperlakukan sebagai warga negara, yang mengandung pengertian bahwa dalam melaksanakan pembinaan, hendaknya sejauh mungkin diusahakan adanya keserasian antara kepentingan dinas dengan kepentingan Pegawai ASN sebagai perorangan, ..."

Hak Asasi Manusia adalah seperangkat hak yang melekat pada hakikat dan keberadaan manusia sebagai mahluk Tuhan Yang Maha Esa dan merupakan anugerahNya yang wajib dihormati, dijunjung tinggi dan dilindungi oleh negara, hukum, Pemerintah, dan setiap orang demi kehormatan serta perlindungan harkat dan martabat manusia. ${ }^{24}$ Hak asasi bukan pemberian negara atau manusia manapun, dan hak itu tetap ada meskipun negara tidak mengaturnya.

Setiap warga negara tidak terkecuali yang berprofesi sebagai ASN memiliki seperangkat hak asasi yang harus dihormati dan dijunjung tinggi. Pengaturan hak asasi manusia dalam konstitusi membawa konsekuensi berupa kewajiban negara untuk melindunginya. Hal ini ditegaskan dalam Pasal 28 I ayat (4) Undang-Undang Dasar Negara Republik Indonesia Tahun 1945 menyatakan bahwa perlindungan, pemajuan, penegakan, dan pemenuhan HAM adalah tanggung jawab negara, terutama Pemerintah. Dalam kerangka perlindungan dan penegakan HAM, kita perlu memperhatikan aspek keseimbangan. ${ }^{25}$

Pertama, adalah keseimbangan antara hak asasi dan kewajiban asasi. Harus dipahami bahwa dalam perumusan hakdengan sendirinya menimbulkan implikasi adanya kewajiban. Kewajiban bersifat inherent di dalam hak itu sendiri. Keduanya bagaikan dua sisi mata uang yang tidak dapat dipisahkan. Di dalam setiap jaminan hak asasi manusia juga terkandung makna kewajiban bagi setiap individu untuk menghormati hak asasi yang dimiliki individu lain. Pasal $28 \mathrm{~J}$ Ayat (1) menyatakan "Setiap orang wajib menghormati hak asasi manusia orang lain dalam tertib kehidupan bermasyarakat, berbangsa, dan bernegara."

Kedua, adalah keseimbangan antara hak kebebasan individu dan hak yang bersifat kolektif. Keduanya berasal dari dua kutub yang berbeda dan sering kali saling berhadap-hadapan, yaitu individualisme dan kolektivisme. Padaawal pembentukan Undang-Undang Dasar Negara Republik Indonesia Tahun 1945 oleh BPUPK pada 1945 telah menghasilkan rumusan yang lebih mencerminkan paham kolektivisme, tetapi pada masa reformasi, tuntutan jaminan perlindungan terhadap hak individu semakin menguat bersamaan dengan tuntutan demokratisasi. Hal itu terwujud dalam rumusan Undang-Undang Dasar Negara Republik Indonesia Tahun 1945. Hasil perubahan yang memberikan jaminan kepada "setiap orang". Namun demikian, hak kebebasan individu tersebut tetap diimbangi dengan aspek hak kolektif. Pemenuhan kepentingan kolektif diperlukan demi terpenuhinya hak dan kebebasan individu yang berada di dalamnya. Dengan demikian, kebebasan individu tidak boleh merugikan hak kolektif, karena sama dengan merugikan hak dan kebebasan individu lain yang jumlahnya lebih banyak. Oleh karena itu Pasal 28 J Ayat (2) Undang-Undang Dasar Negara Republik Indonesia Tahun 1945 menyatakan, bahwa dalam menjalankan hak dan kebebasannya, setiap orang wajib tunduk kepada pembatasan yang ditetapkan dengan undang-undang.

Pembatasan tersebut dapat dilakukan semata-mata untuk menjamin pengakuan serta penghormatan atas hak dan kebebasan orang lain dan untuk memenuhi tuntutan yang adil sesuai dengan pertimbangan moral, nilai-nilai agama, keamanan, dan ketertiban umum dalam suatu masyarakat demokratis. Sejauh mana suatu batasan terhadap hak asasi dalam suatu Undang-undang memenuhi kriteria pembatasan dalam Undang-Undang Dasar Negara Republik Indonesia Tahun 1945.

HAM yang tergolong dalam jenis non-derogable right merupakan intisari (hardcore) HAM. Artinya HAM yang utama dan tidak boleh hilang dalam diri manusia dan hak asasi yang selalu dipertahankan dari diri manusia. Menunjukan bahwa HAM ada dan harus dihormati oleh seluruh umat manusia di dunia dan dalam kondisi apapun sebagai kodrat lahiriah setiap manusia.

Terdapat juga HAM yang diperbolehkan tidak dipenuhi pemberlakuannya. HAM yang tergolong dalam jenis derogable rights (Hak-hak yang boleh dibatasi pemenuhannya) terdiri dari hak untuk menyatakan pendapat, hak untuk bergerak, hak untuk berkumpul, dan hak untuk berbicara. Jaminan pemenuhan terhadap HAM yang dikategorikan derogable rights dapat dibatasi ataupun ditunda pemenuhannya. ${ }^{26}$

\footnotetext{
${ }^{24}$ Jimly Asshiddiqie, Konstitusi dan Hak Asasi Manusia (disampaikan pada Lecture Peringatan 10 Tahun KontraS.Jakarta, 26 Maret 2008), hlm. 6.

${ }^{25}$ Ibid.

${ }^{26}$ Osgar S. Matompo, "Pembatasan Terhadap Hak Asasi Manusia Dalam Perspektif Keadaan Darurat”, Jurnal Media Hukum VOL. 21 NO.1 JUNI 2014, hlm. 61.
} 
Berdasarkan ketentuan perlindungan HAM menurut Undang-Undang Dasar Negara Republik Indonesia Tahun 1945, analisis atas kebijakan netralitas politik ASN menurut Undang-Undang Nomor 5 Tahun 2014 tentang Aparatur Sipil Negara diuraikan sebagai berikut:

a. Hak konstitusional yang diatur dalam kebijakan netralitas politik ASN menurut Undang-Udang Nomor 5 Tahun 2014 Tentang Aparatur Sipil Negara. adalah terkait dengan hak menyatakan pendapat, hak untuk berserikat, dan hak untuk berkumpul bagi ASN. Kebijakan netralitas ini diterbitkan oleh pemerintah dengan harapan agar ASN dapat profesional sehingga dapat mewujudkan pelayanan publik yang baik kepada masyarakat sehingga tercipta pemerintahan yang baik (good governance).

b. Kebijakan netralitas politik ASN sebagaimana tertuang dalam Undang-Undang Nomor 5 Tahun 2014 tentang Aparatur Sipil Negara merupakan pembatasan hak konstitusional ASN dalam kedudukannya sebagai warga negara. Seberapa kecilnya pembatasan tetap pembatasan. Namun pembatasan tersebut memang dimungkinkan dan secara "formalitas prosedural" sah karena ditetapkan dengan Undang-Undang, yaitu Undang-undang Nomor 5 Tahun 2014 Tentang Aparatur Sipil Negara.

c. Hak menyatakan pendapat, hak untuk berserikat, dan hak untuk berkumpul merupakan hak warga yang boleh dibatasi (derogable rights). Apabila suatu negara menghadapi ancaman yang membahayakan eksistensi atau kedaulatan sebagai negara merdeka atau membahayakan keselamatan warga negaranya. Negara tersebut dianggap dapat bertindak apa saja, terlepas dari persoalan legalitas cara-cara yang ditempuh. Namun tindakan-tindakan pembatasan terhadap HAM, harus ditentukan batas-batasannya yang jelas beserta ukuran-ukuran yang tidak membuka peluang terjadinya penyalahgunaan dengan merugikan kepentingan kemanusiaan yang lebih luas.

Menurut Alexander N. Domrin, ada berbagai macam alasan untuk menyatakan keadaan darurat dalam undangundang dari negara-negara didunia seperti yang dilakukan oleh para sarjana hukum Jerman. A Hamann dan HansErnst Folz membagi semua keadaan darurat ke dalam tujuh kategori. A Hamann mengidentifikasikan keadaan darurat sebagai berikut :

1. Invasi asing;

2. Tindakan publik yang bertujuan subversi rezim konstitusional;

3. Pelanggaran serius mengancam ketertiban umum dan keamanan;

4. Bencana,

5. Pemogokan dan kerusuhan di bidang penting dari perekonomian;

6. Gangguan penting dalam pelayanan publik dan

7. Kesulitan di bidang ekonomi dan keuangan. ${ }^{27}$

Pembatasan hak ASN berdasarkan Undang-Undang Nomor 5 Tahun 2014 Tentang Aparatur Sipil Negara memenuhi kriteria yang dapat menyebabkan keadaan darurat terkait dengan pelayanan kepada publik. Jika ASN tidak netral maka akan menimbulkan keadaan darurat terhadap pelayanan publik kepada masyarakat seperti yang terjadi pada zaman orde baru. Oleh sebab itu, pembatasan HAM dari aspek netralitas politik (hak menyatakan pendapat, hak berserikat dan berkumpul) adalah sah.

Undang-Undang Dasar Negara Republik Indonesia Tahun 1945 telah memberikan kriteria pembatasan HAM, yaitu pembatasan dapat dilakukan semata mata untuk menjamin pengakuan serta penghormatan atas hak dan kebebasan orang lain, dan untuk memenuhi tuntutan yang adil sesuai dengan pertimbangan moral, nilai-nilai agama, keamanan, dan ketertiban umum dalam suatu masyarakat demokratis. Kriteria tersebut diuraikan sebagai berikut :

1) Moral, menurut De Vos adalah hal-hal yang mendorong manusia untuk melakukan tindakan-tindakan yang baik sebagai "kewajiban" atau "norma". Moral merujuk kepada tingkah laku yang bersifat spontan seperti rasa kasih, kebesaran jiwa, dan sebagainya, yang kesemuanya tidak terdapat dalam peraturan-peraturan hukum. ${ }^{28}$

2) Agama dipahami sebagai suatu cara pandang dunia, atau serangkaian kepercayaan berkaitan dengan perwujudan dan ungkapan sistem nilai dan jalan hidup dari kercayaan-kepercayaan tersebut.

3) Keamanan adalah suatu keadaan yang ditandai dengan terjaminnya keamanan dan ketertiban masyarakat, tertib dan tegaknya hukum, serta terselenggaranya perlindungan, pengayoman, dan pelayanan kepada masyarakat.

4) Ketertiban umum adalah suatu keadaan yang memungkinkan penyelenggaraan pemerintahan, pelayanan umum, dan kegiatan masyarakat dapat berlangsung sebagaimana biasanya.

Apabila kriteria pembatasan HAM dikaitkan dengan latar belakang dan tujuan kebijakan netralitas politik ASN, maka kebijakan netralitas politik ASN sangat diperlukan dalam rangka mewujudkan penyelenggaraan pemerintahan yang baik (good governance), pelayanan publik, dan kegiatan masyarakat dapat berlangsung sebagaimana mestinya. Alasan pembatasan HAM dalam kebijakan netralitas politik ASN menurut Undang-Undang Nomor 5 Tahun 2014

\footnotetext{
${ }^{27} \mathrm{Ibid}$, hlm. 61.

${ }^{28}$ Wahyudi Kumorotomo, Etika Administrasi Negara, (Jakarta: Rajawali Pers, 2007), hlm. 124.
} 
Tentang Aparatur Sipil Negara merupakan pertimbangan ketertiban umum, yang memenuhi kriteria alasan pembatasan HAM.

Analisis di atas, menunjukkan bahwa terbitnya kebijakan netralitas politik ASN yang tertuang dalam UndangUndang Nomor 5 Tahun 2014 Tentang Aparatur Sipil Negara telah memenuhi elemen-elemen penting yang harus ada pada sebuah negara hukum seperti Negara Indonesia. Pengaturan dan pembatasan hak individu ASN dalam kontestasi politik seperti yang tertuang dalam Undang-Undang Nomor 5 Tahun 2014 tidak melanggar perlindungan HAM sebagaimana yang telah diatur dalam Undang-Undang Dasar Negara Republik Indonesia Tahun 1945. Sebaliknya pembatasan tersebut sangat diperlukan agar ASN tidak terlibat politik praktis, tidak mendapat intervensi dari semua golongan dan partai politik. ASN yang menjalankan asas netralitas dalam kesehariannya tentu akan sangat mendukung pemerintah dalam rangka menciptakan pelayanan yang prima kepada publik dan terciptanya pemerintahan yang baik.

\section{Konsep Netralitas Politik Aparatur Sipil Negara Menurut Islam (Fiqh Siyasah)}

Fiqh siyasah merupakan tarkib idhafi atau kalimat majemuk yang terdiri dari dua kata, yakni fiqh dan siyasah. Secara etimologi, fiqh merupakan bentuk masdhar (gerund) dari tashrifan kata faqiha-yafqahu-fiqhan yang berarti pemahaman yang mendalam dan akurat sehingga dapat memahami tujuan ucapan dan atau tindakan tertentu. Secara terminologi, fiqh lebih populer didefinisikan sebagai ilmu tentang hukum syara' yang bersifat perbuatan yang dipahami dari dalil yang rinci. ${ }^{29}$

Definisi siyasah secara terminologi banyak di kemukakan oleh para yuris Islam. Menurut Abu al-Wafa Ibn 'Aqil, siyasah adalah suatu tindakan yang dapat mengantar rakyat lebih dekat kepada kemaslahatan dan lebih jauh dari kerusakan, kendati pun Rasulullah tidak menetapkannya dan Allah juga tidak menurunkan wahyu untuk mengaturnya. ${ }^{30}$

Nash-nash al-Qur'an, mewajibkan umat Islam mentaati umara (pemimpin) dan melarang menentang mereka. Mengenai hal ini, Allah SWT. berfirman:

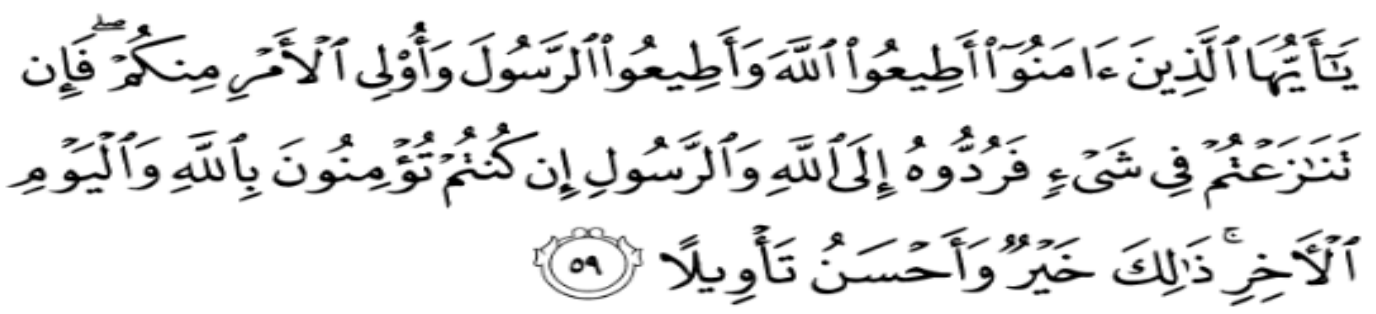

Artinya:

Hai orang-orang yang beriman, taatilah Allah dan taatilah Rasul (Nya), dan ulil amri di antara kamu. Kemudian jika kamu berlainan pendapat tentang sesuatu, Maka kembalikanlah ia kepada Allah (Al Quran) dan Rasul (sunnahnya), jika kamu benar-benar beriman kepada Allah dan hari kemudian. yang demikian itu lebih utama (bagimu) dan lebih baik akibatnya.(QS. An-Nisa: 59).

Diketahui bahwa ketetapan yang dijadikan kaidah oleh para fuqaha, bahwa bentuk inperatif (amr) memberi konsekuensi hukum wajib, selama tidak ada indikasi yang didukung oleh keterangan yang mengubah status wajib menjadi sunah. Dalam ayat ini terdapat perintah mentaati Allah SWT. Rasulullah Saw. serta khalifah, para amir, qadi, menteri serta orang yang mengemban tanggung jawab mengurusi urusan umat Islam.

Prinsip ketaatan mengandung makna bahwa seluruh rakyat tanpa terkecuali berkewajiban mentaati pemerintah, selama penguasa atau pemerintah tidak bersikap zalim (tiran atau diktator), selama itu pula rakyat wajib taat dan tunduk kepada penguasa atau pemerintah ${ }^{31}$. Dalam banyak hadist, Rasulullah menempatkan kepatuhan kepada pemimpin pada posisi kepatuhan kepada diri Rasulullah dan kepatuhan kepada Allah SWT. Imam Bukhari dan Muslim meriwayatkan hadis dari Abi Salamah bin Abdirrahman bahwa dia mendengar Abu Hurairah berkata, bahwa Rasulullah bersada yang artinya:

"Siapa saja yang mentaati aku, maka dia telah mentaati Allah, dan barang siapa yang berbuat maksiat kepadaku, maka dia telah berbuat maksiat kepada Allah, dan siapa saja yang telah mentaati pemimpinku, maka dia telah mentaatiku, sedang siapa saja yang tidak taat kepada pemimpinku, maka dia telah berbuat maksiat kepadaku. (HR. Bukhari dan Muslim”.

\footnotetext{
${ }^{29}$ Ibnu Syarif, Mujar dan Zada, Khamami, Fiqih siyasah; Doktrin dan Pemikiran Politik Islam, (Jakarta: Erlangga, 2008)

${ }^{30}$ Djazuli, Fiqh Siyâsah, (Damascus: Dâr al-Qalam, 2007)

${ }^{31}$ Muhammad Tahir Azhary, Negara Hukum, (Jakarta: Prenada Media group, Cet. Ke- 3, 2007), hlm. 155.
} 
Taat kepada penguasa muslim yang menerapkan hukum-hukum Islam (baik langsung maupun tidak langsung) dalam pemerintahannya, sekalipun zalim dan merampas hak-hak rakyat, selama tidak memerintah untuk melakukan kemaksiatan dan tidak menampakkan kekufuran yang nyata, hukumnya tetap fardu bagi seluruh kaum muslimin. Ketaatan tersebut hukumnya wajib, karena Allah SWT. telah memerintahkan ketaatan kepada penguasa, amir atau Imam. Perintah dengan sebuah indikasi (qarinah) yang menunjukkan adanya suatu keharusan (jazman), yaitu Rasulullah menjadikan ketidaktaatan kepada pemimpin itu sebagai sebuah kemaksiatan kepada Allah dan Rasul. Serta dengan adanya penegasan ( $t a$ "kid) dalam perintah ketaatan tersebut, sekalipun yang menjadi penguasa budak hitam legam. Semuanya itu merupakan indikasi yang menunjukkan bahwa perintah itu menuntut dengan tegas agar dilaksanakan (jazim), maka taat pada pemimpin itu hukumnya fardu.

Berdasarkan penjelasan tersebut di atas, bahwa sikap seorang Aparatur Sipil Negara (ASN) pada pemilihan pemimpin, adalah mendukung terlaksananya pemilihan pemimpin yang mencalonkan dirinya sebagai seorang pemimpin, baik calon pemimpin yang dikenal maupun yang tidak dikenal. Sikap pegawai ASN harus bersikap netral tanpa mendukung salah satu calon pemimpin yang ada. Apabila telah terpilih pemimpin yang baru, maka pegawai ASN harus memiliki sikap loyalitas terhadap pemimpin, mentaati peraturan yang ada, dan menjauhi sikap memusuhinya

\section{SIMPULAN}

Berdasarkan hasil penelitian disimpulkan sebagai berikut:

1. Bentuk kebijakan netralitas politik ASN menurut Undang-Undang Nomor 5 Tahun 2014 tentang Aparatur Sipil Negara tercantum pada Pasal 2 huruf f menyebutkan, bahwa penyelenggaraan kebijakan dan manajemen ASN berdasarkan pada asas netralitas, artinya bahwa setiap pegawai ASN tidak berpihak dengan segala bentuk pengaruh manapun dan tidak memihak kepada kepentingan siapapun.

Terdapat pada Pasal 9 Ayat (2) yang menyatakan, bahwa pegawai ASN harus bebas dari pengaruh dan intervensi semua golongan dan partai politik.Pasal 12, menyatakan Pegawai ASN berperan sebagai perencana, pelaksana, dan pengawas penyelenggaraan tugas umum pemerintahan dan pembangunan nasional melalui pelaksanaan kebijakan dan pelayanan publik yang professional, bebas dari intervensi politik, serta bersih dari praktik korupsi, kolusi dan nepotisme.

2. Kebijakan netralitas politik ASN Menurut Undang-Undang Nomor 5 Tahun 2014 dalam Perspektif Perlindungan HAM, bahwa Undang-Undang Nomor 5 Tahun 2014 Tentang Aparatur Sipil Negara telah memenuhi 4 indikator sebuah negara hukum.Menurut Teori Negara Hukum yang dikembangkan Fredrich Julius Stahl, yaitu ada perlindungan HAM, ada pembagian kekuasaan, pemerintahan yang berdasarkan hukum dan peraturan perundangundangan, dan adaperadilan tata usaha negara.

Dalam perspektif perlindungan HAM di Indonesia, bahwa kebijakan netralitas politik ASN berupa larangan ASN mengekspresikan pilihan politiknya merupakan pembatasan hak konstitusional ASN dalam kedudukannya sebagai warga negara. Pembatasan hak tersebut secara "formalitas-prosedural" adalah sah, karena selain ditetapkan dengan Undang-undang yaitu Undang-Undang Nomor 5 Tahun 2014 Tentang Aparatur Sipil Negara, hak atas kebebasan menyatakan pendapat dan ekspresi tidak termasuk non-derogable rights (Hak yang tidak boleh dibatasi).

Ketiga, menurut fiqh siyasah, bahwa seorang ASN harus memiliki kompetensi dan integritas yang kuat, harus berlaku adil dan tidak boleh memihak dalam menjalankan pekerjaannya serta harus taat dan patuh pada siapapun pemimpin yang terpilih dalam kontestasi politik ditempatnya berkerja.

\section{DAFTAR PUSTAKA}

\section{Buku}

Abdullah, Rozali. Perkembangan Hak Asasi Manusia dan Keberadaan Peradilan Hak Asasi Manusia Di Indonesia.Jakarta: Ghalia Indonesia, 2001.

Agustino, Leo. Dasar-dasar kebijakan Publik. Bandung: Alfabeta, 2008

Azhary, Muhammad Tahir. Negara Hukum. Jakarta: Prenada Media Group, 2007.

Barents, J. Pengantar Ilmu Politik. Jakarta: Erlangga, 1978.

Budiardjo, Meriam. Dasar-Dasar Ilmu Politik, Jakarta : Gramedia, 1982.

Bidang Pengkajian dan Pengembangan Sistem KASN. Pengawasan Netralitas Aparatur Sipil Negara.Jakarta: Komisi Aparatur Sipil Negara, 2018.

Djatmika, Sastra dan Marsono. Hukum Kepegawaian di Indonesia.Jakarta: Djambatan, 1995.

Dwiputrianti, Septiana, dkk. Pengawasan Penegakan Netralitas (Impartiality) Aparatur Sipil Negara. Jakarta:

Komisi Aparatur Sipil Negara, 2019.

Efriza dan Yoyoh Rohaniah. Pengantar Ilmu Politik, Malang : Intrans Publishing, 2015.

Fadjar, Mukthie. Tipe Negara Hukum. Malang: Bayumedia Publishing, 2002. 
Firnas, Muhammad Adian. Politik dan Birokrasi: Masalah Netralitas Birokrasi di Indonesia Era Reformasi. Jakarta: UIN Syarief Hidayatullah, 2016.

Gaffar, Afan. Politik Indonesia Transisi Menuju Demokrasi, Yogyakarta: Pustaka Pelajar, 1999.

Hadjon, Philipus M. Perlindungan Hukum Bagi Rakyat Indonesia: Sebuah Studi Tentang Prinsip-Prinsipnya, Penerapannya oleh Pengadilan dalam Lingkungan Peradilan Umum dan Pembentukan Peradilan Administrasi Negara. Surabaya: Bina Ilmu, 1978.

Hartini, Sri. Hukum Kepegawaian di Indonesia. Jakarta: Sinar Grafika, 2008.

Ida, La Ode. FGD Sistem Pengawasan Netralitas ASN dalam Aspek Politik, Pelayanan Publik, dan Manajemen ASN. Jakarta, 2018.

Islamy, Irfan. Prinsip- prinsip Perumusan Kebijaksanaan Negara. Jakarta: Bumi Aksara, 2009.

Johan, Teuku Saiful Bahri. Hukum Tata Negara dan Hukum Administrasi Negara dalam Tataran Reformasi Ketatanegaraan Indonesia. Yogyakarta: Deepublish, 2018.

Kansil, Cst. Pengantar Ilmu Hukum dan Tata Negara Indonesia. Jakarta: Balai Pustaka, 2002.

Khaldun, Ibnu. Mukaddimah Ibnu Khaldun. Jakarta: Pustaka Al-Kutsar, 2010.

Kumorotomo, Wahyudi. Etika Administrasi Negara. Jakarta: PT. Raja Grafindo Persada, 2005.

Koentjoro, Diana Halim. Hukum Administrasi Negara, Bogor: Ghalia Indonesia, 2004.

Mahmudi. Manajemen Kinerja Sektor Publik. Yogyakarta: UPP AMP YKPN, 2015.

Marbun, S. F. Reformasi Hukum Tata Negara, Netralitas Pegawai Negeri dalam Kehidupan Politik di Indonesia. Yogyakarta: Fakultas Hukum Universitas Islam Indonesia, 1998.

Marzuki, Peter Mahmud. Penelitian Hukum: Edisi Revisi, Jakarta: Kencana Prenada Media Group, 2016.

MD, M. Mahfud dan Marbun S.F. Pokok-Pokok Hukum Administrasi Negara. Yogyakarta: Libert, 1987. . MD, M Mahfud. Pergulatan Polik dan Hukum di Indonesia. Yogyakarta: Gama Media, 1999. . Hukum dan Pilar-Pilar Demokrasi. Yogyakarta: Gama Media, 1999.

. Demokrasi dan Konstitusi di Indonesia. Jakarta: Rineka Cipta, 2000.

Muchsan. Hukum Kepegawaian.Jakarta: Bina Aksara, 1982.

Noer, Deliar. Pengantar ke Pemikiran Politik.Jakarta : Rajawali, 1983.

Nugroho, Riant. Public Policy.Jakarta: PT Elex Media Komputindo, 2008.

Prasojo, Eko. FGD Sistem Pengawasan KASN Terhadap Pelaksanaan Asas Netralitas ASN. Jakarta, 2018.

Riyanto, Astim. Filsafat Hukum. Bandung: Yapemdo, 2002.

SF, Marbun dkk. Dimens-Dimensi Pemikiran Hukum Administrasi Negara. Yogyakarta: UII Press, 2004.

Siagian, Sondang P. Filsafat administrasi.Jakarta: Gunung Agung, 1996.

Surbakti, Ramlan. MemahamiIlmuPolitik.Jakarta: Gramedia, 1991.

. Memahami Konsep Ilmu Politik. Jakarta: PT Grasindo, 2010.

Syamsuddi, Aziz. Proses Dan teknik Penyusunan Undang-undang.Jakarta: Sinar Grafika, 2011.

Tayibnapis, Burhanudin A. Administrasi Kepegawaian; SuatuTinjauan Analitik.Jakarta: Pradnya Paramitha, 1986.

Thoha, Miftah. Birokrasi dan Politik di Indonesia.Jakarta: PT. Raja Grafindo Persada, 2007.

. Birokrasi Pemerintah Indonesia di Era Reformasi. Jakarta: Prenada Media Group, 2008.

Warassih, Esmi. Pranata Hukum, Sebuah Telaah Sosiologis. Semarang: PT Suryandaru Utama, 2005.

Winarno, Budi. Kebijakan Publik :Teori dan Proses. Yogyakarta: Media Pressindo, 2007.

Yazid, Abdullah dkk. Demokrasi dan Hak Asasi Manusia. Malang: Averroes Press, 2007.

Zuhro, Siti. Reformasi Birokrasi Lokal Melalui Pelayanan Terpadu. Jakarta: Lembaga Ilmu Pengetahuan Indonesia (PDF from Jurnal Penelitian Politik, 2008.

Good Governance dan Reformasi Birokrasi di Indonesia.Jakarta: Lembaga Ilmu Pengetahuan Indonesia

(PDF from Jurnal Penelitian Politik, 2016.

\section{Jurnal}

Hartini, Sri. "Penegakan Hukum Netralitas Pegawai Negeri Sipil (PNS)". Jurnal Dinamika Hukum, Volume 9, Nomor 3. 2009

Matompo,Osgar S. "Pembatasan Terhadap Hak Asasi Manusia Dalam Perspektif Keadaan Darurat".Jurnal Media Hukum, Volume 21, Nomor 1.2014

Prasetyo, Teguh. "Rule Of Law Dalam Dimensi Negara Hukum Indonesia", Jurnal Ilmu Hukum Refleksi Hukum, Edisi Oktober 2010.

Sidharta, Bernard Arief. "Kajian Kefilsafatan tentang Negara Hukum”, Jurnal Hukum Jentera, Jakarta: Pusat Studi Hukum dan Kebijakan (PSHK), Edisi 3-Tahun II. 2004 
Tesis

Hartini, Sri. “Kebebasan Berserikat Pegawai Negeri Sipil dalam Partai Politik”.Tesis, Universitas Airlangga, Surabaya, 2000.Tidak dipublikasikan.

Tiara, Piara. "Analisis Putusan Mahkamah Konstitusi Nomor 6/Puu-V/2007 Tentang Keberlakuan Pasal 154 Dan Pasal 155 Kuhp Terhadap Kemerdekaan Menyampaikan Pendapat Di Muka Umum Dalam Perspektif Fiqh Siyasah”. Tesis, Universitas Islam Negeri Raden Fatah, Palembang, 2018. Tidak dipublikasikan.

\section{Peraturan Perundang-undangan}

Indonesia, Undang-Undang Dasar Negara Republik Indonesia Tahun 1945

, Undang-Undang Nomor 39 Tahun 1999 Tentang Hak Asasi Manusia , Undang-Undang Nomor 5 tahun 2014 Tentang Aparatur Sipil Negara

\section{Internet}

Herdiansyah Hamzah, Netralitas ASN dalam pilkada [Online]. Tersedia:http://www.herdi.web.id/netralitas-asn-dalampilkada/. Diunduh tanggal 18 April 2019.

Kezia Gloria, Perlindungan Hak Asasi Manusia (HAM) di Indonesia [Online]. Tersedia: https://www.kompasiana.com/keziagloria4944/5c001a8fab12ae680757f216/perlindungan-hak-asasi-manusiaham-di-indonesia?page=all diunduh tanggal 14 Januari 2019. 